Hellen Nicácio de Araújo ${ }^{1}$ Elda Coelho de Azevedo Bussinguer ${ }^{1}$

\title{
CONSTITUTIONAL PRINCIPLE OF
} EFFICIENCY AND THE PUBLIC POLICIES FOR THE CONTROL OF AEDES AEGYPTI AT THE BRAZILIAN MINISTRY OF HEALTH: DISCOURAGING THE SEARCH FOR MORE EFFECTIVE SOLUTIONS

Princípio constitucional da eficiência e as políticas públicas de monitoramento do Aedes Aegypti do ministério da saúde: desestímulo à busca de soluções mais eficazes

${ }^{1}$ Faculdade de Direito de Vitória. Vitória/ES, Brasil.

Correspondence: Hellen Nicácio de Araújo. E-mail: hbnicacio@gmail.com

Received: 03/02/2019. Revised: 06/11/2019. Approved: 06/25/2019. 


\section{ABSTRACT}

The present study aimed to analyze whether the choice of Brazilian Ministry of Health to monitor the Aedes aegypti mosquito through practically exclusive larval research, conditioning the transfer of financial resources to the municipalities to the achievement of goals related to this monitoring, meets the economicity criteria and satisfaction of the public interest, components of the constitutional principle of efficiency. To this end, after an accurate literature review, we analyzed the division of responsibilities among federal entities regarding environmental surveillance, the system of goals of the Ministry of Health and its influence on the transfer of public money. We examined the forms of monitoring, comparing the various larval research with the use of traps for purposes of entomological research, problematizing the standard established by the Ministry of Health in terms of cost-benefit ratio, as well as the use of system of goals as a form of power centralization. We concluded that, the imposition by the Ministry of Health, to perform the monitoring of Aedes aegypti, by means of larval research, does not meet the economicity criteria neither the satisfaction of the public interest, thus violating the constitutional principle of efficiency.

\section{Keywords}

Aedes aegypti; Constitutional Law; Efficiency; Monitoring.

\section{RESUMO}

O presente estudo teve como objetivo analisar se a opção do Ministério da Saúde de manter o monitoramento do mosquito Aedes aegypti por meio praticamente exclusivo da pesquisa larvária, condicionando o repasse de recursos financeiros aos municípios ao cumprimento de metas relativas a esse acompanhamento, atende aos critérios de economicidade e de satisfação do interesse público, componentes do princípio constitucional da eficiência. Para tanto, após uma acurada revisão de literatura, analisamos a divisão de atribuições entre os entes federados no que diz respeito à vigilância ambiental, o sistema de metas do Ministério da Saúde e sua influência no repasse de verbas públicas. Examinamos as formas de monitoramento, comparando a pesquisa larvária com a utilização de armadilhas para fins de levantamento entomológico, problematizando o padrão estabelecido pelo Ministério da Saúde em termos de relação custo-benefício, bem como a utilização do sistema de metas como forma de centralização de poder. Concluímos que a imposição, pelo Ministério da Saúde, da realização de monitoramento do Aedes aegypti por meio da pesquisa larvária não atende aos critérios de economicidade nem de satisfação do interesse público, violando, portanto, o princípio constitucional da eficiência.

\section{Palavras-Chave}

Aedes aegypti.; Direito Constitucional; Eficiência; Monitoramento. 


\section{Introduction}

The Brazilian population was surprised between the end of 2015 and the beginning of 2016 by a phenomenon never seen before: many children, mainly born in the Northeast of the country, had microcephaly for no known reason. In March 2016, with the progress of the research, it was possible to establish the relationship between microcephaly that affected newborns with Zika, a disease transmitted by Aedes aegypti. Such discovery brought to light another serious problem very known to Brazilians: the inability of the governments to deal with the cited mosquito and the diseases transmitted by it. According to an epidemiological bulletin released by the Ministry of Health, 159,718 cases of dengue fever, 65,480 cases of chikungunya and 3,625 of acute disease caused by the Zika virus were confirmed in the period from $12 / 31 / 2017$ to $12 / 10 / 2018^{1}$.

As pointed out by Silva, Mariano and Scopel ${ }^{2}$, the traditional methods of epidemiological control for vector control, once effective, are no longer sufficient, either by the ability of the mosquito to adapt to cities, or by changing people's lifestyle (women working outside their homes, increase in urban violence, etc.), either because of a lack of political disposition for basic sanitation works. However, despite these variables, the Ministry of Health still adopts home visitation (larval research) performed by health and endemic agents as the standard form of monitoring of Aedes aegypti.

It is a model based on the bimonthly visitation of all properties belonging to the infested municipalities - where there is dissemination and maintenance of the vector in the households - in epidemic periods or not ${ }^{3}$, which requires time and large amount of health and endemic agents, materials and equipment. This strategy necessarily requires a considerable amount of financial resources, without, however, achieving the desired result, since epidemics of this diseases caused by this vector occur every year.

The large volume of financial resources and time required to perform the larval research, together with the poor results of this public policy, call into question the pillars of the management model of public administration adopted by Brazil. The emphasis of this model is the approximation between the public and private

\footnotetext{
${ }^{1}$ MINISTÉRIO DA SAÚDE - MS. Monitoramento dos casos de dengue, febre de chikungunya e doença aguda pelo vírus Zika até a Semana Epidemiológica 49 de 2018. Boletim Epidemiológico, v. 49, dez. 2018. Available at: http://portalarquivos2.saude.gov.br/images/pdf/2019/janeiro/02/2018-067.pdf. Accessed on: 28 Jan. 2019.

2SILVA, Jesiel Souza; MARIANO, Zilda de Fátima; SCOPEL, Irací. Dengue no Brasil e as políticas de combate ao Aedes aegypti: da tentativa de erradicação às políticas de controle, Revista Hygeia, v. 4. n. 6, p. 171, 2008. Available at: http://www.seer.ufu.br/index.php/hygeia/article/view/16906/9317. Accessed on: 16 Jun. 2017. ${ }^{3}$ MINISTÉRIO DA SAÚDE - MS. Diretrizes Nacionais para Prevenção e Controle de Epidemias de dengue. Brasília-DF: Ministério da Saúde, 2009. p. 53. (Série A. Normas e Manuais Técnicos). Available at: http:// bvsms.saude.gov.br/bvs/publicacoes/diretrizes_nacionais_prevencao_controle_dengue.pdf. Accessed on: 16 Jun. 2017.
} 
administration system, in the search for a service provision with the lowest cost to the public administration, but also satisfying the needs of the population, balancing the cost-benefit equation.

The Constitutional Amendment no. 19/1998 was enacted, which, in addition to other determinations, included efficiency in the list of basic principles of public administration. From this legal framework and the brief improvement of the country's financial conditions in the first decade of the 2000s, resulting from the economic stabilization after the Real Plan, some municipalities sought other ways to monitor the Aedes aegypti, different that announced by the Ministry of Health, which reduced costs, but also had more effective results.

In this context, scientific research indicates that the use of latest technologies, such as egg traps of Aedes aegypti or adult mosquitoes, could be a less costly alternative to ${ }^{4}, 5$ and more successful ${ }^{6}$ for the monitoring of the vector.

However, even in the face of recent changes in the daily life of society, the adaptation of the vector to cities and advances in scientific research, the Ministry of Health remains refractory to changes, requiring the achievement of goals of larval research, including as a conditioning factor in the transfer of financial resources to municipalities.

Given this situation, it is necessary to question whether the option of the Ministry of Health to keep monitoring the Aedes aegypti through larval research, practically exclusively, conditioning, even, the transfer of financial resources to the municipalities to their compliance, meets the economicity criteria and satisfaction of the public interest, components of the constitutional principle of efficiency.

To answer this question, we analyzed: the division of responsibilities among federal entities regarding the provision of health services, especially in environmental surveillance; the basic characteristics of the constitutional principle of efficiency; and the system of goals of Ministry of Health's monitoring, as well as its influence on the transfer of public funds to the monitoring of the vector actions. The monitoring methods were also analyzed, comparing the larval research with the use of traps for

\footnotetext{
${ }^{4}$ FURLOW, Bruce M.; YOUNG, Willian W. Larval surveys compared to ovitrap surveys for detecting Aedes aegypti and Aedes triseriatus. Mosquito News, v. 30, n. 3, p. 468-470, 1970. Available at: https://www. biodiversitylibrary.org/content/part/JAMCA/MN_V30_N3_P468-470.pdf. Accessed on: 09 Jun. 2019.

${ }^{5}$ RESENDE, Marcelo Carvalho de; SILVA, Ivoneide Maria da; EIRAS, Álvaro Eduardo. Avaliação da operacionalidade da armadilha MosquiTRAP no monitoramento de Aedes aegypti. Epidemiologia. Serviços de Saúde, Brasília, v. 19, n. 4, p. 330, dez. 2010. Available at: http://scielo.iec.gov.br/scielo.php?script=sci_ arttext\&pid=S1679-49742010000400003\&Ing=pt\&nrm=iso. Accessed on: 17 Jun. 2017; 26 fev. 2019. http://dx.doi.org/10.5123/S1679-49742010000400003.

${ }^{6}$ BRAGA, Ima Aparecida et al. Comparação entre pesquisa larvária e armadilha de oviposição, para detecção de Aedes aegypti. Revista da Sociedade Brasileira de Medicina Tropical, Uberaba, v. 33, n. 4, p. 347-353, ago. 2000. Available at: http://www.scielo.br/scielo.php?script=sci_arttext\&pid=S0037$86822000000400003 \&$ Ing=en\&nrm=iso. Accessed on: 16 Jan. 2019. http://dx.doi.org/10.1590/S003786822000000400003.
} 
the purpose of entomological survey and problematizing the standard established by the Ministry of Health regarding the cost-benefit ratio required by the constitutional principle of efficiency. It is worth nothing that, in this article, the terms "efficiency" and "effectiveness" are not treated as synonyms: the first is considered in its legal connotation, understood in the cost-benefit ratio, while the second is used in its colloquial sense, of producing valid effects.

For this purpose, a literature review and documentary survey were carried out, mainly on the specific legislation and other normative provisions of the Ministry of Health, such as national guidelines, manuals and information, as well as scientific articles on the subject available in the worldwide computer network.

\section{Allocations and forms of funding for the provision of health services by state entities}

The Federal Constitution of 1988 (CF/88) established that health is a right of all, and it is the duty of the State to guarantee it through actions aimed at reducing the risk of diseases and other injuries, through a decentralized Brazilian National Health Service (SUS) in which the community participates, aiming at the integral care of the population, with priority for preventive activities without prejudice to assistance servives ${ }^{7}$. Thus, it is up to the SUS, among other attributions, to carry out epidemiological surveillance, which comprises the set of actions that provide knowledge, identification and prevention of any change in determinant and conditioning factors of individual or collective health, with the objective of recommending and adopting measures to prevent and control diseases or injuries, as determined by Law no. 8.080/1990 .

Later, with the Pan-American Conference of Health and Environment in the Context of Sustainable Development (Copasad), held in 1995, the Ministry of Health undertook actions towards the formation of a a National System of Epidemiological and Environmental Surveillance in Health that would extend to all levels of the federation and whose objective was to establish the relationship between the themes of health and environment ${ }^{9}$. With the structuring of this system, became part of environmental surveillance in health the analysis and monitoring of biological risk factors, among other vectors of diseases, to Aedes

\footnotetext{
${ }^{7}$ BRASIL. Constituição da República Federativa do Brasil de 1988. Available at: http://www.planalto.gov.br/ ccivil_03/constituicao/constituicaocompilado.htm. Accessed on: 30 Aug. 20206.

${ }^{8}$ BRASIL. Lei n. 8.080 de 19 de setembro de 1990. Dispõe sobre as condições para a promoção, proteção e recuperação da saúde, a organização e o funcionamento dos serviços correspondentes e dá outras providências. Available at: http://www.planalto.gov.br/ccivil_03/leis/L8080.htm. Accessed on: 13 Jan. 2019.

${ }^{9}$ MINISTÉRIO DA SAÚDE - MS. Fundação Nacional de Saúde. Vigilância ambiental em saúde. Brasília-DF: Fundação Nacional de Saúde, 2002. p. 13. Available at: http://bvsms.saude.gov.br/bvs/publicacoes/ manual_sinvas.pdf. Accessed on: 13 jan. 2019.
} 
aegypti, in order to map risk areas in certain territories using entomological surveillance and its relations with epidemiological surveillance. It should be noted that, in this system, entomological surveillance is responsible for the analysis of characteristics, presence and infestation indices and the evaluation of the efficacy of vector control methods; and, the epidemiological surveillance, for monitoring the incidence and prevalence of these diseases, as well as the impact of control actions. The actions carried out within the surveillance system also interact with the network of public health laboratories and with sanitation actions, aiming at the control or elimination of risks ${ }^{10}$.

In this structure, the distribution of competencies among the state entities established by Law 8,080/1990 was maintained, that is, it is up to the Union, through the National Health Foundation (Funasa), to define and coordinate the epidemiological and environmental surveillance system; to the states, regional coordination and, in addition, the implementation of actions; and, to the municipalities, the implementation of the actions. Thus, it is primarily up to the municipalities to directly execute the actions of combat, control and monitoring of the Aedes aegypti.

Regarding the financing of these activities, although each federal entity has a minimum limit of their own investment in health, most of the services are funded by the Union, which transfers resources to the states and municipalities through the National Health Fund (FNS). The amounts of this transfer are defined based on the Agreed and Integrated Programming (PPI), negotiated in the Bipartite Intermanagers Commissions (state and municipalities) and Tripartite (Union, states and municipalities), formalized in acts of state and federal managers and previously approved in the respective State Health Councils and the National Health Council ${ }^{11}$. Thus, the main form of transfer of financial resources from the Union to the states and municipalities is the transfer between funds, which consists in the automatic and regular remittance of amounts directly from the National Health Fund to the State and Municipal Funds, regardless of agreement or similar instrument.

Specifically regarding the financing of health surveillance actions, Ordinance no. 1,378/2013 of the Ministry of Health determined that the transfers would be made through two headings: the Fixed Floor of Health Surveillance (PFVS) and the Variable Floor of Health Surveillance (PVVS) ${ }^{12}$. The PFVS is composed of a per capita value established on the basis of the stratification of the federated units

\footnotetext{
${ }^{10}$ MINISTÉRIO DA SAÚDE - MS. Fundação Nacional de Saúde. Vigilância ambiental em saúde cit.. p. 23.

${ }^{11}$ ld. Ibid., p. 30.

${ }^{12}$ MINISTÉRIO DA SAÚDE - MS. Levantamento rápido de índices para Aedes aegypti - LIRAa - para vigilância entomológica do Aedes aegypti no Brasil. Brasília-DF: Ministério da Saúde, 2013. 84p. Available at: http:// bvsms.saude.gov.br/bvs/publicacoes/manual_liraa_2013.pdf. Accessed on: 12 Nov. 2017.
} 
according to the epidemiological situation and the degree of operational difficulty for the execution of actions in health surveillance ${ }^{13}$. The amounts passed on by the Union must be suplemented by the states and municipalities, through own revenue. This is the ordinary source of resources for epidemiological and environmental surveillance work, and managers should be accountable in the annual management report. In contrast, the PVVS consists of specific financial incentives for strategic action, transferred through adhesion of the federal entities to plans and projects established by the Ministry of Health in which counterparts, goals and punishments are defined in case of non-compliance ${ }^{14}$.

Although, initially, the PVVS does not have as its purpose the financial incentive of actions of combat, control and monitoring the Aedes aegypti, it is also used for this purpose since $2016^{15}$. For example, Ordinance no. 2,303/2017 of the Ministry of Health authorized the transfer of R\$30,486,026.72 from the PVVS to the states and municipalities, referring to the second tranche of resources for funding of contingency actions for the prevention and control of the vector Aedes aegypti due to the epidemiological scenario of yellow fever ${ }^{16}$.

As observed from the structure described, the ordinary activities of epidemiological and environmental surveillance should be fully funded by the own resources of the states and municipalities and by the PFVS, and only the extraordinary and strategic activities supported by the PVVS.

Also regarding the financing of control actions of Aedes aegypti, it should be noted that the Tripartite Inter-Managers Commission has established the obligation to carry out the Entomological Survey of Infestation by Aedes aegypti, which must be sent by the state health departments to the Ministry of Health. Failure to comply with this rule implies the suspension of the transfer of resources, not only of the PVVS, but also from PFVS (Resolution MS/CIT n. 12/2017 ${ }^{17}$; Ordinance MS

\footnotetext{
${ }^{13}$ MINISTÉRIO DA SAÚDE - MS. Levantamento rápido de índices para Aedes aegypti - LIRAa - para vigilância entomológica do Aedes aegypti no Brasil, cit.

${ }^{14}$ Id. Ibid.

${ }^{15}$ MINISTÉRIO DA SAÚDE - MS. Portaria n. 3.129, de 28 de dezembro de 2016. Autoriza repasse no Piso Variável de Vigilância em Saúde (PVVS) do Componente de Vigilância em Saúde de recurso financeiro para implementação de ações contingenciais de prevenção e controle do vetor Aedes aegypti. Available at: http://bvsms.saude.gov.br/bvs/saudelegis/gm/2016/prt3129_28_12_2016.html. Accessed on: 30 Agu. 2020.

${ }^{16}$ MINISTÉRIO DA SAÚDE - MS. Portaria n. 2.303, de 11 de setembro de 2017. Autoriza repasse no Piso Variável de Vigilância em Saúde (PVVS) do Componente de Vigilância em Saúde de recurso financeiro referente à segunda parcela conforme Portaria n. 3.129/GM/MS, de 28 de dezembro de 2016. Available at: http://bvsms.saude.gov.br/bvs/saudelegis/gm/2017/prt2303_15_09_2017.html. Accessed on: 16 Jan. 2019.

${ }^{17}$ MINISTÉRIO DA SAÚDE - MS. Comissão Intergestores Tripartite - CIT. Resolução n. 12, de 26 de janeiro de 2017. Torna obrigatório o levantamento entomológico de Infestação por Aedes aegypti pelos municípios e o envio da informação para as Secretarias Estaduais de Saúde e destas, para o Ministério da Saúde. Available at: http://www.saude.gov.br/images/pdf/2017/janeiro/33/Resolucao12_2701.pdf. Accessed on: 30 Agu. 2020.
} 
n. $\left.3.469 / 2017^{18}\right)$. It is necessary to highlight that, for the correct completion of the aforementioned Entomological Survey, the municipality is conditioned to the exact compliance with the provisions contained in the National Guideline for Prevention and Control of Dengue established by the Ministry of Health, that is, except for the possibility of assuming the costs with own resources, which is an exception, any measure of monitoring the vector, in addition to those recommended by the Union, remains undermined by the lack of funding.

In this sense, as Paula Freitas et al. ${ }^{19}$, municipal managers face several difficulties in carrying out the combat, control and monitoring of the Aedes, since they need to obey a vector control system "outdated, costly and inefficient", maintained by a vertical national policy which does not take into account the local reality, in addition to the real financing difficulties for the maintenance of services in the strict terms recommended by the Ministry of Health - and practically without the possibility of reviewing these practices, even if the alternatives prove to be more successful.

Thus, in order to try to guarantee financial resources to fund epidemiological and environmental surveillance actions, municipalities are obliged to remain strictly within the parameters and goals set by the Ministry of Health ${ }^{20}$, to which they often adhere, knowing that they will have to unfold to comply with them, since the financial resources, as a rule, will be used to cover the costs of ordinary activities. In other words, as the health system is verticalized and underfunded, municipalities assume new obligations, with new financing, to have access to resources that will serve to fund routine activities, being overloaded and always in deficit.

It should be emphasized, however, that the system of setting goals, obligations and consequent punishments in case of non-compliance used by the Ministry of Health is characteristic of the management model of administration, partially implemented in Brazil in the 1990s with the objective of providing more efficiency to the public service. According to this public management model, the State should

\footnotetext{
${ }^{18}$ MINISTÉRIO DA SAÚDE - MS. Portaria n. 3.469, de 18 de dezembro de 2017.Suspende a transferência de recursos financeiros do Piso Fixo de Vigilância em Saúde (PFVS) do Bloco de Vigilância em Saúde dos municípios que não cumprirem a obrigatoriedade de envio do levantamento entomológico de Infestação por Aedes aegypti, conforme previsão do art. $1^{\circ}$ da Resolução CIT $n^{\circ} 12$, de 26 de janeiro de 2017. Available at: http://bvsms.saude.gov.br/bvs/saudelegis/gm/2017/prt3469_22_12_2017.html. Accessed on: 25 Jun. 2019.

${ }^{19}$ FREITAS, Paula de Souza Silva et al. As políticas públicas de saúde em situações de emergência e o surto de zika vírus: a voz dos gestores de saúde. In: CONGRESSO BRASILEIRO DE POLÍTICA, PLANEJAMENTO E GESTÃO EM SAÚDE, 2017, 3. Anais... Natal, 2017. Available at: https://pdfdocumento.com/anais-do3-congresso-de-politica-clique-aqui-e-baixe-o-pdf-abrasco_59f37b951723dda7db3d6396.html. Accessed on: 21 Jan. 2019.

${ }^{20}$ SOUSA, André de. Governo adia meta para combate a focos da dengue. Até janeiro foram visitados apenas 15,21\% de domicílios, O Globo on-line, 22 jan. 2016.p. 172. Available at: https://oglobo.globo. com/sociedade/saude/governo-adia-meta-para-combate-focos-da-dengue-18523545\#ixzz4wrbBUnJP. Accessed on: 29 out. 2017.
} 
incorporate some typical practices of the private sector, such as: professionalization of management; setting performance standards and evaluation measures; emphasis on the control of results; decentralisation of services; introduction of the merit system; and expenses reduction. All of these practices focus on efficiency, efficacy, and productivity ${ }^{21}$, a topic to be deepened in item II below.

\section{Constitutional principle of efficiency and its use by the Ministry of Health to encourage health surveillance actions}

\section{Constitutional principle of efficiency}

The principle of efficiency was listed among the basic principles of public administration in Constitutional Amendment no. $19 / 1998^{22}$, enacted in the context of a Brazilian administrative reform in which forms of state action more similar to those of private initiative were advocated: the managerial model. This public management model emerged in England in 1980, having as main objectives, in the theory, the reduction of the State and the improvement of the quality of public administration to provide it with greater governability, focusing on the development and outcome of public policies - in turn, aimed at reducing and controlling public expenditure and improving the provision of public services ${ }^{23}$.

Even before its inclusion expressed in the Brazilian constitutional text, the principle of efficiency was already provided for in several provisions of the $\mathrm{CF} / 88$, such as Articles 74, item II, and 144, paragraph 7, among others, and it cannot be conceived that the public administration, in the Democratic Rule of Law, has authorization to be inefficient ${ }^{24}$. Also in the doctrine, even before the inclusion of this principle among the basic principles of public administration, efficiency was already considered a duty of the public administrator, who could not be content to perform his activities only within legality, but should seek positive results for the public service and which were satisfactory to meet the needs of the ${ }^{25}$ community.

\footnotetext{
${ }^{21}$ CABRAL NETO, Antônio; CASTRO, Alda Maria Duarte Araújo. Gestão escolar em instituições de ensino médio: entre a gestão democrática e a gerencial. Educação \& Sociedade, Campinas, v. 32, n. 116, p. 747, set. 2011. Available at: http://www.scielo.br/scielo.php?script=sci_arttext\&pid=S0101-73302011000300008\&lng= pt\&nrm=iso. Accessed on: 06 de Jun. 2017. https://doi.org/10.1590/S0101-73302011000300008.

${ }^{22}$ CÂMARA DOS DEPUTADOS. Emenda Constitucional n. 19, de 1988. Modifica o regime e dispõe sobre princípio e normas da Administração Pública, Servidores e Agentes políticos, controle de despesas e finanças públicas e custeio de atividades a cargo do Distrito Federal, e dá outras providências. Available at: https://www2.camara.leg.br/legin/fed/emecon/1998/emendaconstitucional-19-4-junho-1998-372816norma-pl.html. Accessed on: 30 Agu. 2020.

${ }^{23}$ CABRAL NETO, Antônio; CASTRO, Alda Maria Duarte Araújo. op. cit., p. 748.

${ }^{24}$ MODESTO, Paulo. Notas para um debate sobre o princípio da eficiência, Revista do Serviço Público, v. 51, n. 2, p. 110, 2000. Available at: https://revista.enap.gov.br/index.php/RSP/article/view/328. Accessed on: 03 Jun. 2017. https://doi.org/10.21874/rsp.v51i2.328.

${ }^{25}$ MEIRELLES, Hely Lopes. Direito administrativo brasileiro. 37. ed. São Paulo: Malheiros Editores, 2016.
} 
Thus, although this is not a novelty in the legal system, but due to its importance, especially regarding this study, we seek, among some national authors, a conceptualization of the cited principle. For Kings ${ }^{26}$ and Bugarin ${ }^{27}$, the concept of efficiency is equivalent to the principle of economicity, provided for in Article 70 of the $\mathrm{CF} / 88$, in that it expresses the rationality with which the selection and allocation of economic resources in productive processes must be made. Medauar ${ }^{28}$, Gasparini ${ }^{29}$ and Modesto ${ }^{30}$ understand that the principle of efficiency determines that the direct and indirect administration, must act in a quicker, accurate and economic way to produce results that meet the needs of the population. In contrast, Mello ${ }^{31}$ stresses that the principle of efficiency would be only one facet of the principle of legality, which has been long treated in Italian law as a principle of good administration and by which administrative activity must develop in a more congruent, timely and appropriate way to the purposes to be achieved, through the choice of means and the occasion to be used, its not a question of mere deontological aspiration, but a current and strictly legal duty.

Grotti $^{32}$, in turn, asserts that efficiency is characterized by an economic concept that introduced into the Brazilian legal system relative parameters of optimal use of available resources for the maximum achievement of desired results. For this author, it is not only a question of demanding that the State achieve the desired results with the means at its disposal, but that these results are the best possible, thus reaching a level of positive quality or qualitative dimension. This time, efficiency concerns the fulfillment of the purposes of the public service in order to meet the needs citizens in the leass costly way possible, extracting from the available resources the highest quality in its provision. From these concepts, it is possible to noted that the principle of efficiency has an undeniable legal content, but also an economic one, characteristic of the so-called School of Economic Analysis of Law (Law and Economics), which defended the influence of economic valuation on the formation of legal rules as a way to make them more effective and real ${ }^{33}$.

\footnotetext{
${ }^{26}$ REIS, Palhares Moreira. A eficiência na Constituição. Correio Brasiliense, Suplemento Direito e Justiça, Brasília-DF, p. 5, fev. 2000.

${ }^{27}$ BUGARIN, Paulo Soares, o princípio constitucional da eficiência: um enfoque doutrinário multidisciplinar, Revista do TCU, Brasília, v. 32, n. 87, p. 49, jan./mar. 2001. Available at: http://revista.tcu.gov.br/ojs/index. php/RTCU/article/viewFile/919/984. Accessed on: 17 de Jun. 2017.

${ }^{28}$ MEDAUAR, Odete. Direito administrativo moderno. 3. ed. São Paulo: Editora Revista dos Tribunais, 1999. p. 145.

${ }^{29}$ GASPARINI, Diógenes. Direito administrativo. 10. ed. São Paulo: Editora Saraiva, 2005. p. 21.

${ }^{30}$ MODESTO, Paulo. op. cit., p. 114.

${ }^{31}$ MELLO, Celso Antônio Bandeira de. Curso de direito administrativo. 31. ed. rev. e atual. São Paulo: Malheiros Editores, 2014. p. 125.

${ }^{32}$ GROTTI, Dinorá Adelaide Musetti. O serviço público e a Constituição Brasileira de 1988. São Paulo: Malheiros Editores, 2003. p. 298-299.

${ }^{33}$ ZYLBERSZTAJN, Décio; SZTAJN, Rachel. Análise econômica do direito e das Organizações. In: ZYLBERSZTAJN, Décio; SZTAJN, Rachel (Orgs.). Direito e economia. 6. reimpr. Rio de Janeiro: Elsevier Editora, 2005. p. 23.
} 
For Posner ${ }^{34}$, efficiency would be one of the meanings of justice and the foundation of the scale of values of politics, in moral and in Law, which the man would be the rational maximizer of his life goals - that is, how to be economically rational, he will inevitably analyze the cost-benefit ratio between the possible options, choosing the one that best suits his interests, maximizing his own satisfactions.

Thus, efficiency is expressed in two inseparable strands: economicity, understood in the need for the rational use of public resources, avoiding waste; and, the fulfillment of an interest (value) - which, in the case of public administration, is invariably the interest public, always considering the optimal cost-benefit ratio of administrative activity. In order to encourage the efficient performance of public managers, the controls of their activity are no longer performed by setting procedures (bureaucratic management) to focus on the control of results, to achieve the agreed goals ${ }^{35}$, systematic adopted, in principle, by the Ministry of Health regarding the control and monitoring of Aedes aegypti.

\section{Guidelines of the Ministry of Health, methods of entomological surveillance and their possible results, under the aspect of the principle of efficiency}

In 2009, the Ministry of Health edit a manual entitled National Guidelines for Prevention and Control of Dengue Epidemics, with the aim of: "organize, guide, facilitate, expedite and standardize the actions necessary for a supportive, coordinated and articulated response among the members of the National Health System"36. In this manual, two basic forms of monitoring the vector were established: entomological surveillance and actions to combat the mosquito to be perform in bimonthly work cycles, which include six annual visits to the same property, covering $100 \%$ of the households in the municipality ${ }^{37}$.

The home visit carried out by the health agent has the function of verifying the presence of mosquito breeding sites, guiding the residents on their elimination and on preventive measures, being also used to index survey of infestation rates. Entomological surveillance aims to promote the collection of information related to the vector, such as its geographical distribution, infestation rates and predominant deposits; according to the Ministry of Health, it must be carried out through larval research, that is, inspection of immature forms (larvae and pupae) in all deposits of

\footnotetext{
${ }^{34}$ POSNER, Richard. El análisis económico del derecho. 2. ed. México: Fondo de Cultura Económica, 2007. p. 10.

${ }^{35}$ BRESSER-PEREIRA, Luiz Carlos. A administração pública gerencial: estratégia e estrutura para um novo Estado. Brasília-DF: Enap, 1996. p. 12. (Texto para discussão n. 9). Available at: http://repositorio.enap. gov.br/bitstream/1/817/1/9texto.pdf. Accessed on: 19 Jan. 2019.

${ }^{36}$ MINISTÉRIO DA SAÚDE - MS. Diretrizes Nacionais para Prevenção e Controle de Epidemias de dengue, cit., p. 12.

${ }^{37}$ Id. Ibid., p. 69.
} 
the property, using a light source (flashlight, mirror ${ }^{38}$. This survey is carried out by sampling, either by systematic sample - index survey (LI), suitable for smaller cities, since the location must be considered as a whole -, or by conglomerates - division by neighborhoods and blocks, wit the Larval Index Rapid Assay for Aedes aegypti (LIRA $a$ ), the most used in the country ${ }^{39}$. The LIRA $a$ must be carried out every four months and aims to obtain infestation maps in a "quick" way, in order to instruct managers to define the vector combat routines, and is even indicated for use in municipalities with infestation, in situations either epidemic or low transmission ${ }^{40}$.

However, conducting LIRA $a$ is quite complex and involves field agents, the supervisor and the team coordinator, in addition to the laboratory service, since it proceeds through the collection of larvae and eggs. Thus, in order to carry out this survey, the following measures ${ }^{41}$ must be adopted:

- The field agent must visit 20 to 25 properties per day, noting that the inspection of each block must be initiated by the first property, with a clockwise shift; count four properties after the property inspected and then inspect the sixth property (second of the sample) and so on, inspecting one property in five, which corresponds to $20 \%$ of the existing properties in the selected block.

- During the inspection, a thorough larval search must be carried out on the properties defined in the stratum, that is, to verify $100 \%$ of the potential deposits of Aedes aegypti breeding sites existing in the property, collecting the larvae/ eggs found.

- After inspection and collection, the agent must complete the form Boletim de Campo e Laboratório (BCL) (Field and Laboratory Bulletin) and, at the end of the day, pass it on, duly completed and accompanied by the collected material, to the supervisor.

- In contrast, the team supervisor should forward to the laboratory the BCL and partial summaries with the collected samples, sending to the aforementioned section and the partial summary by stratum, whose data will only be consolidated by the coordinator after the laboratory analysis of the collected material.

All this procedure, archaic and extremely bureaucratic, has a minimum cycle of two months to present the results. But that is not all: since it is a method carried out within the households, the larval research still faces other difficulties, such as the increasing number of closed properties (since visits occur only during

\footnotetext{
${ }^{38}$ MINISTÉRIO DA SAÚDE - MS. Diretrizes Nacionais para Prevenção e Controle de Epidemias de dengue, cit., p. 71.

${ }^{39}$ Id. Ibid., p. 72-73.

${ }^{40}$ Id. Ibid., p 73.

${ }^{41}$ MINISTÉRIO DA SAÚDE - MS. Levantamento rápido de índices para Aedes aegypti - LIRAa - para vigilância entomológica do Aedes aegypti no Brasil, cit.
} 
the day, when most people are in work activities) ${ }^{42,43}$ and the refusal of residents to receive the health agent, which also makes it very difficult the activities to monitor the vector in this way. Wermelinger ${ }^{44}$ also recalls the existence of other difficulties in accessing potential breeding sites, such as: water tanks suspended or on roofs, attics, slabs, wells, ditches, cisterns, high gutters, galleries and underground spaces that require training, equipment and physical and emotional preparation (patience, ability to dialogue and understand the fears and difficulties of the residents) of the service professional to carry out an adequate inspection, which also does not correspond to the Brazilian reality.

Finally, even after completing all the steps, the results presented may not be useful or partial, either because they fail to indicate the presence of adult females, which makes it impossible to provide information on the population of mosquitoes in current reproductive activity, because they do not produce specific information, which portrays a certain moment, but intervals that vary from 12 to 15 days, in the fast mode, and two months, in the traditional ${ }^{45}$.

Even aware of all these difficulties and the financial reality of the municipalities, the Ministry of Health conditions the transfer of financial resources to the municipal entities to the achievement of the larval research goals foreseen in the Agreed and Integrated Programming, whose disregard may imply the suspension of financial transfers and also notification to the Court of Auditors, the Public Prosecutor's Office and the Federal Police to initiate an investigation ${ }^{46}$.

Specifically in relation to LIRA $a$, as already mentioned above, the obligation to carry out the survey by the municipalities and the punishment in case of non-compliance were agreed in meetings held by the Tripartite Intermanagers Commissions (CTI); these normative decisions were used by the Ministry of Health to justify the

\footnotetext{
${ }^{42}$ PESSANHA, José Eduardo Marques et al. Avaliação do Plano Nacional de Controle da Dengue. Cadernos de Saúde Pública, Rio de Janeiro, v. 25, n. 7, p. 1640, jul. 2009. Available at: http://www.scielo.br/scielo. php?script=sci_arttext\&pid=S0102-311X2009000700024\&Ing=en\&nrm=iso. Accessed on: 17 Jun. 2017. https://doi.org/10.1590/S0102-311X2009000700024.

${ }^{43}$ TAUIL, Pedro Luiz. Urbanização e ecologia do dengue. Cadernos de Saúde Pública, Rio de Janeiro, v. 17, supl. p. 101, 2001. Available at: http://www.scielo.br/scielo.php?script=sci_arttext\&pid=S0102-311X200100070 0018\&lng=en\&nrm=iso. Accessed on: 19 Jun. 2017. https://doi.org/10.1590/S0102-311X2001000700018.

${ }^{44}$ WERMELINGER, Eduardo Dias. As reivindicações da ABRASCO para as ações de controle do Aedes aegypti no Brasil. Cadernos Saúde Coletiva, Rio de Janeiro, v. 24, n. 4, p. 386-387, dez. 2016. Available at: http:// www.scielo.br/scielo.php?script=sci_arttext\&pid=S1414-462X2016000400385\&lng=en\&nrm=iso. Accessed on: 16 Jan. 2019. http://dx.doi.org/10.1590/1414-462x201600040064.

${ }^{45} \mathrm{ACYOLI}$, Ridelane Veiga. O uso de armadilhas de oviposição (ovitrampas) como ferramenta para o controle da dengue. 2006. Dissertação (Mestrado em Saúde Pública) - Centro de Pesquisas Aggeu Magalhães, Fundação Oswaldo Cruz, Recife, 2006. p. 86. Available at: https://www.arca.fiocruz.br/bitstream/ icict/3956/2/000065.pdf. Accessed on: 19 Jan. 2019.

${ }^{46}$ MINISTÉRIO DA SAÚDE - MS. Portaria n. 1.172, de 15 de junho de 2004. Regulamenta a NOB SUS 01/96 no que se refere às competências da União, estados, municípios e Distrito Federal, na área de vigilância em saúde, define a sistemática de financiamento e dá outras providências. Available at: http://bvsms.saude. gov.br/bvs/saudelegis/gm/2004/prt1172_15_06_2004.html. Accessed on: 16 Jan. 2019.
} 
suspension of the transfer of resources, including the Fixed Floor Health Surveillance, to those municipalities that do not comply with the obligation to send LIRA $a$ (Resolution MS/CIT n. 12/2017; Ordinance MS No. 3,469/2017). It should be noted that the decisions adopted by CIT are taken after discussions in the Technical Chamber of Health Surveillance, which is composed of members of the National Council of Health Secretaries (Conass) and the National Council of Municipal Health Secretaries (Conasems), which, in front of the difficulties faced by themselves, should seek more efficient alternatives, but which, either for conservatism or fear of making new investments, remain stuck to old practices so criticized by technicians and the academia.

Thus, given the difficulties identified and considering that the option of governments is still the mechanical and chemical control of the vector, Pessanha et al. ${ }^{47}$ suggest that the actions are focused only on the areas where the presence of Aedes aegypti is frequently observed, with strict monitoring mainly in the dry and cold periods, when there is a residual population of mosquitoes, using the system of traps - therefore, giving up the current routine, since this strategy has not proven to be viable in field activities.

Currently, there are three basic types of traps on the Brazilian market: ovitraps, which are used to collect eggs; larvitrampas, which collect larvae; and the traps that promote the capture of adult mosquitoes, by using the chemical attractants of the mosquito females ${ }^{48}$. Several scientific researches have been conducted with the objective of comparing the two forms of monitoring Aedes aegypti: larval research (recommended by the Ministry of Health) and the traps. For Resende, Silva and Eiras ${ }^{49}$, the use of traps facilitates the monitoring of Aedes aegypti because the control agent does not need to enter private properties because it is a method performed outside the home (peridomicílio) - in public areas, for example -, which puts you at an advantage over other methods, which depend on the presence and authorization of the resident. In the same sense, field research developed by Acyoli ${ }^{50}$, Braga and Valle $^{51}$, Braga et al..$^{52}$ and Nascimento ${ }^{53}$ demonstrate that the use of traps to monitor

\footnotetext{
${ }^{47}$ PESSANHA, José Eduardo Marques et al. op. cit., p. 1640.

${ }^{48}$ FUNDAÇÃO OSWALDO CRUZ - FIOCRUZ. Nota Técnica n. 3/2014/IOC-FIOCRUZ/DIRETORIA. Avaliação de armadilhas para a vigilância entomológica de Aedes aegypti com vistas à elaboração de novos índices de infestação. 2014. p. 2. Available at: http://www.fiocruz.br/ioc/media/nota_tecnica_ioc_3.pdf. Accessed on: 12 Nov. 2017.

${ }^{49}$ RESENDE, Marcelo Carvalho de; SILVA, Ivoneide Maria da; EIRAS, Álvaro Eduardo. op. cit., p. 330.

${ }^{50}$ ACYOLI, Ridelane Veiga. op. cit., p. 92.

${ }^{51}$ BRAGA, Ima Aparecida, VALLE, Denise. Aedes aegypti: vigilância, monitoramento da resistência e alternativas de controle no Brasil. Epidemiologia e Serviços de Saúde, Brasília, v. 16, n. 4, p. 297, dez. 2007. Available at: http://scielo.iec.gov.br/scielo.php?script=sci_arttext\&pid=S1679-49742007000400007\&lng=pt\&nrm =iso. Accessed on: 17 Jan. 2019. http://dx.doi.org/10.5123/S1679-49742007000400007.

${ }^{52}$ BRAGA, Ima Aparecida et al. Comparação entre pesquisa larvária e armadilha de oviposição, para detecção de Aedes aegypti, cit., p. 347.

${ }^{53}$ NASCIMENTO, Fellipe Albano Melo do. Padronização e implementação do uso de armadilhas de oviposição nas ações de monitoramento do mosquito Aedes aegypti (Diptera: Culicidae) no municipio de Natal, RN. 2017. 57f. Dissertação (Mestrado em Ciências Biológicas) - Centro de Biociências, Universidade Federal do Rio Grande do Norte, Natal, 2017. p. 47. Available at: https://repositorio.ufrn.br/jspui/ handle/123456789/24059. Accessed on: 17 Jan. 2019.
} 
Aedes aegypti has advantages over larval research due to greater sensitivity, the generation of more quantitative information about the vector population, the better indication of risk, the greater ease of operationalization and at the lowest cost, and is therefore, operationally viable on a large scale.

Specifically regarding the comparison between larval research and traps, studies carried out by Fay and Eliason ${ }^{54}$, Jakob and Bevier ${ }^{55}$ and Furlow and Young ${ }^{56}$ indicate that the use of traps is more economical because it allows the monitoring of a larger area by fewer agents, which represents a decrease in operational costs in relation to larval research. In the same sense, according to Resende, Silva and Eiras ${ }^{57}$, it would be necessary only $10 \%$ of the percentage of agents in a neighborhood to monitor an area, approximately four times bigger than the current standard, which also represents an economy with personnel, transport equipment etc.

Researchers from the Fundação Oswaldo Cruz (Fiocruz) also carried out studies on the use of traps for monitoring vector, comparing the effectiveness (that is, without analyses in relation to the operating costs of each methodology) of the different types of equipment among themselves and with the larval index. The conclusion was that, despite the differences between the models, all presented more satisfactory results than the method ordinarily proposed by the Ministry of Health $^{58}$. It should be noted that, with this study, Fiocruz does not advocate the replacement of the control agent by the exclusive use of the trap, but points to the possibility of using this equipment as an effective estrategy of entomological control, especially considering its superiority in relation to the method of larval index. Moreover, monitoring with traps is a method compatible with the aggregation of new technologies, such as the transmission of information via smartphone and/or tablet, eliminating the need to fill out the form by hand and the use of paper, which generates time and money savings, enabling more comprehensive and faster monitoring of the vector. This form of monitoring of Aedes aegypti has already been tested in several municipalities, and is currently used throughout the state of Espírito Santo. According to the State Department of Health of Espírito Santo, the use of this methodology implied the optimization of vector control,

\footnotetext{
${ }^{54}$ FAY, R. W.; ELIASON, D. A. A preferred oviposition site as surveillance method for Aedes aegypti. Mosquito News, v. 26, n. 4, p. 531-537. 1966. Available at: https://www.biodiversitylibrary.org/content/part/JAMCA/ MN_V26_N4_P531-535.pdf. Accessed on: 09 Jun. 2019.

${ }^{55}$ JAKOB, W.L.; BERVIER, G. A. Evaluation of ovitraps in the U.S. Aedes aegypti Eradication Program. Mosquito News, v. 29 , n. 4, p. $650-653$, 1969. Available at: https://archive.org/details/cbarchive_116007_ evaluationofovitrapsintheusaed1969. Accessed on: 09 de Jun. 2019.

${ }^{56}$ FURLOW, Bruce M.; YOUNG, Willian W. op. cit., p.468.

${ }^{57}$ RESENDE, Marcelo Carvalho de; SILVA, Ivoneide Maria da; EIRAS, Álvaro Eduardo. op. cit., p. 336.

${ }^{58}$ FUNDAÇÃO OSWALDO CRUZ - FIOCRUZ. Nota Técnica n. 3/2014/IOC-FIOCRUZ/DIRETORIA. Avaliação de armadilhas para a vigilância entomológica de Aedes aegypti com vistas à elaboração de novos índices de infestação, cit., p. 5.
} 
especially regardind the speed of access to information, the provision of quality information and the reduction of operating costs of the system ${ }^{59,60}$.

The Ministry of Health lists the possibility of using traps for the purposes of entomological surveys, but only in locations negative or low vector infestation or, still in strategic areas, such as ports and airports, in order to monitor infestation in these locations ${ }^{61}$. In addition to these hypotheses, the use of traps has also been expanded for monitoring in non-infested municipalities, since the provisions of the National Guidelines for Prevention and Control of Dengue (Ordinance MS No. 2,303/2017) were observed. Thus, for the Ministry of Health, monitoring the vector through traps would only be acceptable in exceptional situations or in negative or non-infested municipalities, and not as an ordinary monitoring instrument, insisting on the index survey, which dates back to the 1980s, or in LIRA $a$, whose implementation is complex, time-consuming and expensive - all of this despite the results presented by the surveys, which suggest the effectiveness of the traps even in terms of lower cost.

As discussed in item II.1, in the Brazilian management model, efficiency in public service is a constitutional duty that conditions the administrator' performance to the cumulative fulfillment of its two aspects: the satisfaction of the public interest (value) and rational use of available public resources, avoiding waste (economicity). To achieve these objectives, it is possible to set goals/rewards to encourage the production of positive results, which must be agreed among stakeholders.

Regarding the vector, the option of the Ministry of Health for maintaining larval research - which, according to most researchers in the field, as already indicated, is archaic, difficult to perform, time consuming, imprecise and expensive - to the detriment of other more modern forms, such as traps, are not justified, especially under the principle of efficiency, since it is not the best way to serve the public interest, due to all the difficulties described above, nor with regard to economicity, since it requires many financial resources to be executed, especially when compared to the other way of carrying out the entomological survey.

It is also important to remember that this activity is carried out directly by the municipalities, many of which are entirely dependent on the financial transfers of the Union, including extraordinary ones, to keep minimally the health services working. Thus, as there is no other way to obtain these financial resources, municipalities,

\footnotetext{
${ }^{59}$ SESA apresenta resultados do uso do monitoramento inteligente do Aedes. News, 2018. Available at: https://www.es.gov.br/Noticia/sesa-apresenta-resultados-do-uso-do-monitoramento-inteligente-do-aedes. Accessed on: 16 Jan. 2019.

${ }^{60}$ ESPÍRITO Santo tem mais de 6 mil armadilhas para identificar locais com infestação do Aedes aegypti. Notícias, 2019. Available at: https://dengue.saude.es.gov.br/Not\%C3\%ADcia/espirito-santo-tem-mais-de6-mil-armadilhas-para-identificar-locais-com-infestacao-do-aedes-aegypt. Accessed on: 11 de Jun. 2019.

${ }^{61}$ MINISTÉRIO DA SAÚDE - MS. Diretrizes Nacionais para Prevenção e Controle de Epidemias de dengue, cit., p.77.
} 
including those that started using other technologies as less costly alternatives, end up being forced to also carry out larval research, attracting the burden of violating the principle of efficiency.

In contrast, when the Ministry of Health sets goals and procedures for carrying out a certain activity and imposes them as a condition for the municipalities to have access to credits - and also establishes personal punishments to managers, in case of non-compliance -, one cannot talk about incentive, pact/partnership, but a real intervention of the Union in municipal health management. It is a total distortion of the objective of the system of goals, whose purpose is to provide more efficient public services and which becomes an instrument of control and concentration of power.

This is exactly what happens with the methods of entomological survey: the Ministry of Health does not prohibit the use of traps or more modern technologies and methods, but it discourages their use since, if the municipality wants to adopt them, will need to pay for it with their own resources and, even so, will not be exempted from achievement the goals established for larval research, under penalty of loss of resources of the Fixed Floor of Health Surveillance and of the managers responding civilly, administratively and criminally.

However, despite all these difficulties, some municipalities in the country have made efforts to continue investing in monitoring by traps. Positive results have been achieved with this, both in terms of satisfactory public interest provision and in terms of economic aspects.

\section{Final Considerations}

The principle of efficiency is one of the basic pillars of public administration, since it aims to achieve the optimal relationship between cost and benefit. In this sense, the principle is not satisfied with the mere fulfillment of the obligation or the provision of the public service in any way, and it is the duty of the administrators to seek, continuously and incessantly, alternatives, methods and procedures that make the provision of public service increasingly suitable to the demands of the population, with the lowest costs. In the case of the control of Aedes aegypti, this duty is even more relevant, especially because the diseases caused by this vector can leave very serious sequelae, such as the congenital Zika syndrome, and even lead to death, which unfortunately occurs year by year. It is essential that public actions of combat, control and monitoring of the mosquito were the best and the most appropriate, however this is not the Brazilian reality.

The Ministry of Health, refractory to changes in methods and practices, continues to insist on larval research as the main form of monitoring the vector, including conditioning the transfer of federal resources to its compliance, 
although many researchers point to its inefficiency, considering it archaic, difficult to execute, time consuming, imprecise and expensive - which, in itself, already constitutes a violation of the principle of efficiency, since the method does not serve the public interest because it does not have quality that meets the needs of citizens, besides being difficult to execute and extremely expensive, which also offends the economicity aspect.

In the opposite sense, other methods and technologies arise, such as the use of traps for carrying out the entomological survey, which cannot be wasted or underused, since the search for more effective solutions is a duty of the public administrator, who cannot be distance from scientific evolution nor alien to the possibilities currently offered by technological advancement.

Given the possibility of adopting a more efficient public policy, it was expected that the Ministry of Health would encourage the adoption of new technologies aiming at the quality of public services at the lowest possible cost. However, what happens is the opposite: by practically imposing the realization of the larval research, conditioning the transfer of financial resources to achieve its goals, including under penalty of personal accountability of the public manager, in addition to meeting the pillars of the principle of efficiency, the Ministry of Health operates a real intervention in health services, competence of the municipal, distorting the system of goals, which no longer has the function of encouraging the better provision of public services to be transformed into an instrument of centralization of power by the Federal Government.

Thus, the option of the Ministry of Health to keep monitoring the Aedes aegypti through larval research, practically exclusively, conditioning, inclusive, the transfer of financial resources to municipalities to their compliance, disregard the economicity criteria or public interest satisfaction, violating the constitutional principle of efficiency.

\section{References}

ACYOLI, Ridelane Veiga. O uso de armadilhas de oviposição (ovitrampas) como ferramenta para o controle da dengue. 2006. Dissertação (Mestrado em Saúde Pública) - Centro de Pesquisas Aggeu Magalhães, Fundação Oswaldo Cruz, Recife, 2006. Available at: https://www. arca.fiocruz.br/bitstream/icict/3956/2/000065.pdf. Accessed on: 19 Jan. 2019.

BRAGA, Ima Aparecida et al. Comparação entre pesquisa larvária e armadilha de oviposição, para deteç̧ão de Aedes aegypti. Revista da Sociedade Brasileira de Medicina Tropical, Uberaba, v. 33, n. 4, p. 347-353, ago. 2000. Available at: http://www.scielo.br/scielo.php?script=sci_ arttext\&pid=S0037-86822000000400003\&lng=en\&nrm=iso. Accessed on: 16 Jan. 2019. http:// dx.doi.org/10.1590/S0037-86822000000400003. 
BRAGA, Ima Aparecida, VALLE, Denise. Aedes aegypti: vigilância, monitoramento da resistência e alternativas de controle no Brasil. Epidemiologia e Serviços de Saúde, Brasília, v. 16, n. 4, p. 295-302, dez. 2007. Available at: http://scielo.iec.gov.br/scielo.php?script=sci_ arttext\&pid=S1679-49742007000400007\&lng=pt\&nrm=is. Accessed on: 17 Jan. 2019. http:// dx.doi.org/10.5123/S1679-49742007000400007.

BRESSER-PEREIRA, Luiz Carlos. A administração pública gerencial: estratégia e estrutura para um novo Estado. Brasília-DF: Enap, 1996. (Texto para discussão n. 9). Available at: http:// repositorio.enap.gov.br/bitstream/1/817/1/9texto.pdf. Accessed on: 19 Jan. 2019.

BUGARIN, Paulo Soares, o princípio constitucional da eficiência: um enfoque doutrinário multidisciplinar, Revista do TCU, Brasília, v. 32, n. 87, p. 39-50, jan./mar. 2001. Available at: http://revista.tcu.gov.br/ojs/index.php/RTCU/article/viewFile/919/984. Accessed on: 17 de Jun. 2017.

CABRAL NETO, Antônio; CASTRO, Alda Maria Duarte Araújo. Gestão escolar em instituições de ensino médio: entre a gestão democrática e a gerencial. Educação \& Sociedade, Campinas, v. 32, n. 116, p. 745-770, set. 2011. Available at: http://www.scielo.br/scielo. php? script $=$ sci_arttext\&pid $=S 0101-73302011000300008 \& \operatorname{lng}=$ pt $\&$ nrm $=$ iso. Accessed on: 06 de Jun. 2017. https://doi.org/10.1590/S0101-73302011000300008.

ESPÍRITO Santo tem mais de 6 mil armadilhas para identificar locais com infestação do Aedes aegypti. Notícias, 2019. Available at: https://dengue.saude.es.gov.br/Not\%C3\%ADcia/ espirito-santo-tem-mais-de-6-mil-armadilhas-para-identificar-locais-com-infestacao-doaedes-aegypt. Accessed on: 11 de Jun. 2019.

FAY, R. W.; ELIASON, D. A. A preferred oviposition site as surveillance method for Aedes aegypti. Mosquito News, v. 26, n. 4, p. 531-537. 1966. Available at: https://www. biodiversitylibrary.org/content/part/JAMCA/MN_V26_N4_P531-535.pdf. Accessed on: 09 Jun. 2019.

FREITAS, Paula de Souza Silva et al. As políticas públicas de saúde em situações de emergência e o surto de zika vírus: a voz dos gestores de saúde. In: CONGRESSO BRASILEIRO DE POLÍTICA, PLANEJAMENTO E GESTÃO EM SAÚDE, 2017, 3. Anais... Natal, 2017. Available at: https://pdfdocumento.com/anais-do-3-congresso-de-politica-clique-aqui-e-baixe-o-pdfabrasco_59f37b951723dda7db3d6396.html. Accessed on: 21 Jan. 2019.

FUNDAÇÃO OSWALDO CRUZ - FIOCRUZ. Nota Técnica n. 3/2014/IOC-FIOCRUZ/ DIRETORIA. Avaliação de armadilhas para a vigilância entomológica de Aedes aegypti com vistas à elaboração de novos índices de infestação. 2014, p. 1-7. Available at: http://www.fiocruz. br/ioc/media/nota_tecnica_ioc_3.pdf. Accessed on: 12 Nov. 2017.

FURLOW, Bruce M.; YOUNG, Willian W. Larval surveys compared to ovitrap surveys for detecting Aedes aegypti and Aedes triseriatus. Mosquito News, v. 30, n. 3, p. 468-470, 1970. Available at: https://www.biodiversitylibrary.org/content/part/JAMCA/MN_V30_N3_P468470.pdf. Accessed on: 09 Jun. 2019.

GASPARINI, Diógenes. Direito administrativo. 10. ed. São Paulo: Editora Saraiva, 2005. 
GROTTI, Dinorá Adelaide Musetti. O serviço público e a Constituição Brasileira de 1988. São Paulo: Malheiros Editores, 2003.

JAKOB, W.L.; BERVIER, G. A. Evaluation of ovitraps in the U.S. Aedes aegypti Eradication Program. Mosquito News, v. 29, n. 4, p. 650-653, 1969. Available at: https://archive.org/details/ cbarchive_116007_evaluationofovitrapsintheusaed1969. Accessed on: 09 de Jun. 2019.

MEDAUAR, Odete. Direito administrativo moderno. 3. ed. São Paulo: Editora Revista dos Tribunais, 1999.

MEIRELLES, Hely Lopes. Direito administrativo brasileiro. 37. ed. São Paulo: Malheiros Editores, 2016.

MELLO, Celso Antônio Bandeira de. Curso de direito administrativo. 31. ed. rev. e atual. São Paulo: Malheiros Editores, 2014.

MINISTÉRIO DA SAÚDE - MS. Diretrizes Nacionais para Prevenção e Controle de Epidemias de dengue. Brasília-DF: Ministério da Saúde, 2009. 157p. (Série A. Normas e Manuais Técnicos). Available at: http://bvsms.saude.gov.br/bvs/publicacoes/diretrizes_nacionais_ prevencao_controle_dengue.pdf. Accessed on: 16 Jun. 2017.

MINISTÉRIO DA SAÚDE - MS. Fundação Nacional de Saúde. Vigilância ambiental em saúde. Brasília-DF: Fundação Nacional de Saúde, 2002. Available at: http://bvsms.saude.gov. br/bvs/publicacoes/manual_sinvas.pdf. Accessed on: 13 Jan. 2019.

MINISTÉRIO DA SAÚDE - MS. Levantamento rápido de índices para Aedes aegypti - LIRAa - para vigilância entomológica do Aedes aegypti no Brasil. Brasília-DF: Ministério da Saúde, 2013. 84p. Available at: http://bvsms.saude.gov.br/bvs/publicacoes/manual_liraa_2013.pdf. Accessed on: 12 Nov. 2017.

MINISTÉRIO DA SAÚDE - MS. Monitoramento dos casos de dengue, febre de chikungunya e doença aguda pelo vírus Zika até a Semana Epidemiológica 49 de 2018. Boletim Epidemiológico, v. 49, dez. 2018. Available at: http://portalarquivos2.saude.gov.br/images/pdf/2019/ janeiro/02/2018-067.pdf. Accessed on: 28 Jan. 2019.

MODESTO, Paulo. Notas para um debate sobre o princípio da eficiência, Revista do Serviço Público, v. 51, n. 2, p. 105-120, 2000. Available at: https://revista.enap.gov.br/index.php/RSP/ article/view/328. Accessed on: 03 Jun. 2017. https://doi.org/10.21874/rsp.v51i2.328.

NASCIMENTO, Fellipe Albano Melo do. Padronização e implementação do uso de armadilhas de oviposição nas ações de monitoramento do mosquito Aedes aegypti (Diptera: Culicidae) no município de Natal, RN. 2017. 57f. Dissertação (Mestrado em Ciências Biológicas) - Centro de Biociências, Universidade Federal do Rio Grande do Norte, Natal. Available at: https:// repositorio.ufrn.br/jspui/handle/123456789/24059. Accessed on: 17 Jan. 2019.

PESSANHA, José Eduardo Marques et al. Avaliação do Plano Nacional de Controle da Dengue. Cadernos de Saúde Pública, Rio de Janeiro, v. 25, n. 7, p. 1637-1641, jul. 2009. Available at: http://www.scielo.br/scielo.php?script=sci_arttext\&pid=S0102-311X2009000700024\&lng=e n\&nrm=iso. Accessed on: 17 Jun. 2017. https://doi.org/10.1590/S0102-311X2009000700024. 
POSNER, Richard. El análisis económico del derecho. 2. ed. México: Fondo de Cultura Económica, 2007.

REIS, Palhares Moreira. A eficiência na Constituição. Correio Brasiliense, Suplemento Direito e Justiça, Brasília-DF, fev. 2000.

RESENDE, Marcelo Carvalho de; SILVA, Ivoneide Maria da; EIRAS, Álvaro Eduardo. Avaliação da operacionalidade da armadilha MosquiTRAP no monitoramento de Aedes aegypti. Epidemiologia. Serviços de Saúde, Brasília, v. 19, n. 4, p. 329-338, dez. 2010. Available at: http://scielo.iec.gov.br/scielo.php?script=sci_arttext\&pid=S1679-49742010000400003\&ln g=pt\&nrm=iso. Accessed on: 17 Jun. 2017; 26 fev. 2019. http://dx.doi.org/10.5123/S167949742010000400003.

SESA apresenta resultados do uso do monitoramento inteligente do Aedes. Notícias, 2018. Available at: https://www.es.gov.br/Noticia/sesa-apresenta-resultados-do-uso-domonitoramento-inteligente-do-aedes. Accessed on: 16 Jan. 2019.

SILVA, Jesiel Souza; MARIANO, Zilda de Fátima; SCOPEL, Irací. Dengue no Brasil e as políticas de combate ao Aedes aegypti: da tentativa de erradicação ás políticas de controle, Revista Hygeia, v. 4. n. 6, p. 163-175, 2008. Available at: http://www.seer.ufu.br/index.php/ hygeia/article/view/16906/9317. Accessed on: 16 Jun. 2017.

SOUSA, André de. Governo adia meta para combate a focos da dengue. Até janeiro foram visitados apenas 15,21\% de domicílios, O Globo on-line, 22 jan. 2016. Available at: https:// oglobo.globo.com/sociedade/saude/governo-adia-meta-para-combate-focos-da-dengue18523545\#ixzz4wrbBUnJP. Accessed on: 29 Oct. 2017.

TAUIL, Pedro Luiz. Urbanização e ecologia do dengue. Cadernos de Saúde Pública, Rio de Janeiro, v. 17, supl. p. 99-102, 2001. Available at: http://www.scielo.br/scielo.php?script=sci_ arttext\&pid=S0102-311X2001000700018\&lng=en\&nrm=iso. Accessed on: 19 Jun. 2017. https://doi.org/10.1590/S0102-311X2001000700018.

WERMELINGER, Eduardo Dias. As reivindicações da ABRASCO para as ações de controle do Aedes aegypti no Brasil. Cadernos Saúde Coletiva, Rio de Janeiro, v. 24, n. 4, p. 385-387, dez. 2016. Available at: http://www.scielo.br/scielo.php?script=sci_arttext\&pid=S1414-462X2 016000400385\&lng=en\&nrm=iso. Accessed on: 16 Jan. 2019. http://dx.doi.org/10.1590/1414$462 \times 201600040064$.

ZYLBERSZTAJN, Décio; SZTAJN, Rachel. Análise econômica do direito e das Organizações. In: ZYLBERSZTAJN, Décio; SZTAJN, Rachel (Orgs.). Direito e economia. 6. reimpr. Rio de Janeiro: Elsevier Editora, 2005. p. 19-29. 
Principle of efficiency and public policies for monitoring of Aedes aegypti

Hellen Nicácio de Araújo - PhD candidate in Fundamental Rights and Guarantees by Faculdade de Direito de Vitória (FDV); masters student in Public Security by Unidade Vila Velha (UVV); specialization in Procedural Law by Centro de Estudos Superiores de Maceió (CESMAC). Public defender in the state of Espírito Santo. Vitória/ES, Brazil. E-mail: hbnicacio@gmail.com

Elda Coelho de Azevedo Bussinguer - Free Teaching by the Universidade do Rio de Janeiro (UniRio); PhD in Bioethics by the Universidade de Brasília (UnB); Master in Fundamental Rights and Guarantees by the Faculdade de Direito de Vitória (FDV). Coordinator of the Graduate Program in Law at FDV. Vitória/ES, Brazil. E-mail: elda.cab@gmail.com 